PAPER PENGANTAR FILSAFAT

\title{
BUDAYA TORAJA DAN HUBUNGANNYA DENGAN PEMBENTUKAN KARAKTER MASYARAKAT TORAJA
}

\author{
jeinnovitasallo01@gmail.com
}

\begin{abstract}
ABSTRAK
Budaya merupakan cara atau pola hidup yang berkembang serta dimiliki bersama oleh sekelompok orang, dan diwariskan secara turun temurun. Budaya Toraja merupakan salah satu budaya di Propinsi Sulawesi Selatan yang dikenal masih sangat kental. Budaya terbentuk oleh beberapa faktor, diantaranya dibentuk oleh sistem kepercayaan, politik,adat istiadat, juga dibentuk oleh karya-karya seni. Tana Toraja memiliki berbagai budaya yang unik yaitu Rambu Solo' dan Rambu Tuka'. Budaya Toraja cukup terkenal hingga di Luar Negeri. Tujuan dari penulisan paper ini adalah untuk mengetahui tentang Budaya Toraja dengan Karakter Manusia Toraja. Yang menjadi point penting dalam penulisan paper ini ialah bagaimana memahami budaya Toraja dengan hubungannya dengan Karakter Manusia Toraja karena mengenali karakter setiap manusia itu sangat penting, khususnya dalam budaya Toraja. Juga lewat penulisan paper ini menggambarkan kebijaksanaan orang Toraja Tradisional, yang menunjukkan bagaimana mereka merawat kualitas berpikir serta kualitas pertumbuhan mereka. Metode yang digunakan adalah dengan membaca jurnal kemudian mengembangkan dari setiap referensi yang dikutip.
\end{abstract}

Kata Kunci:Budaya Toraja,Karakter,Manusia 


\section{PENDAHULUAN}

Peradaban manusia Toraja sudah ada jauh hari sebelum datangnya intuisi sekolah. Mereka tumbuh dan berkembang secara tradisional, dengan norma dan tatanan nasional yang melahirkan entitas budaya serta identitasnya. Budaya mereka merupakan hasil olah rasa dan karsa menjadi daya tarik bagi berbagai pihak dari luar untuk diteliti. Persoalan identitas dalam budaya ini melahirkan pertanyaan, bagaimana orang Toraja menghidupi pendidikan karakter sehingga tumbuh menjadi manusia yang dewasa dan berbudaya? Hal ini menjadi penting sebab identitas tongkonan dari seseorang menjadi standar pengakuan sosial bagi eksistensi dirinya sebagai manusia Toraja. Dalam rangka tumbuh kembangnya pendidikan karakter manusia Toraja, acapkali spirit eskatologis ini berperan dalam heuristika pendidikan orang Toraja, kendati secara praktikal masih samar-samar. Budaya Kelisanan orang Toraja menjadi salah satu medium untuk melatih anak-anak untuk menghadapi persoalan secara lumrah (problem solving) dengan kreatif. Inilah sebabnya heuristika dipilih sebagai cara pandang untuk melihat kecerdasan orang Toraja tradisional/primitif. ${ }^{1}$ Manusia Toraja (dalam pengertian primitif), sejarah dilihat sebagai pengungkapan ontologi-mistis yang terus menerus mengulangi tindakan primordial secara sadar melalui pemaknaan isyarat maupun paradigma (seperti siklus spiral). Sejarah diatur oleh arketipe, maksudnya tindakan hanya dilakukan sejauh meniru dan mengulangi arketipe ${ }^{2}$. Terbentuknya emosi dan karakter anakanak Toraja tradisional berkaitan langsung dengan berbagai manifestasi nilai yang mereka gugu (rujuk); dan hal ini diadopsi serta ditularkan secara langsung melalui keteladanan (eksemplari), sebagaimana disebut di atas, yakni mentiro dan ma'peolai. Adapun nilai-nilai etika yang mereka hidupi langsung tersebut antara lain: mengasihi, keadilan, merasa salah, malu, berani, sabar/menahan diri, menyimak, mengajukan pendapat, bersekutu, membagi kelebihan, dan lain-lain. ${ }^{3}$

\footnotetext{
${ }^{1}$ Rannu Sanderan, "Heuristika dalam Pendidikan Karakter Manusia Toraja," BIA' Jurnal Teologi dan Pendidikan Kristen Kontekstual 3, no 2 (December 19, 2020):306-307, https: //doi.org/10.34307/b.v3i2.213

${ }^{2}$ Rannu Sanderan, "Heuristika dalam Pendidikan Karakter Manusia Toraja," BIA' Jurnal Teologi dan Pendidikan Kristen Kontekstual 3, no 2 (December 19, 2020):309, https: //doi.org/10.34307/b.v3i2.213

${ }^{3}$ Rannu Sanderan, "Heuristika dalam Pendidikan Karakter Manusia Toraja," BIA' Jurnal Teologi dan Pendidikan Kristen Kontekstual 3, no 2 (December 19, 2020):317, https: //doi.org/10.34307/b.v3i2.213
} 


\section{TUJUAN PENULISAN}

Tujuan dari penulisan makalah atau paper ini ialah untuk memberi penjelasan atau pemahaman tentang budaya, kemudian yang kedua untuk mengetahui bagaimana hubungan Budaya Toraja dengan Karakter Masyrakat Toraja. Yang ketiga untuk mengetahui bagaimana pembentukan karakter seseorang.

\section{MANFAAT PENULISAN}

Manfaat dari penulisan paper atau makalah ini adalah untuk menambah wawasan bagi pelajar maupun masyarakat khususnya masyarakat Toraja dalam hal pembentukan karakter yang baik. 


\section{PEMBAHASAN}

"Sikap moral" menegaskan orientasi pada norma-norma sebagai standar-standar yang harus saya ikuti. Sedangkan ethos menegaskan bahwa sikap itu adalah sikap yang sudah menetap dan biasa, sesuatu yang nyata-nyata mempengaruhi, yang menentukan bagaimana saya atau sekelompok orang mendekati dan melakukan sesuatu. Maka istilah "ethos" mengungkapkan "semangat seseorang atau sekelompok orang sejauh di dalamnya termuat tekanan-tekanan moral untuk nilai-nilai moral tertentu. Maka ethos kerja adalah sesuatu yang dimiliki atau tidak dimiliki dan yang tidak dapat dipaksa ${ }^{4}$. Sikap moral lebih merujuk pada perkenalan norma-norma sebagai syarat atau standar yang harus di pedomani. Ethos memperlihatkan semangat seseorang atau individu atau sekumpulan orang yang digunakan untuk melihat setiap moral untuk nilai tertentu. Sikap moral dalam budaya Toraja sangat di junjung tinggi karena lewat karakter seseorang bisa dinilai bagaimana kepribadian seseorang. Dalam budaya Toraja, karakter seseorang mencerminkan bagaimana mereka di didik.

Tekanan utama dalam pengembangan karakter secara tradisional berangkat dari nilai luhur konteks budaya lokal. Nilai luhur tersebut mengarahkan penekanan nilai intrinsik (intangible) tentang norma dan hukum moral dalam dirinya sendiri sang anak (hati nurani) maupun bagi komunitas basis di mana ia bertumbuh. Acapkali pengalaman langsung menarik perhatian anak, khususnya ketika seorang anak diperhadapkan pada pilihan baik atau buruk, maka pada saat yang sama ia akan dipengaruhi oleh nilai yang ditanamkan dalam setiap aktivitasnya (seperti yang diuraikan di atas). Dengan kata lain, modeling dari dinamika edukasi karakter sepatutnya diupayakan melalui cara mendampingi anak untuk mengembangkan, menguatkan dan makin memperjelas nilai karakter yang dianutnya. Keberpihakan pada anak seyogianya menjadi ideologi utama dlam pendidikan bukan terutama pada pembangunan fisik ${ }^{5}$. Pengembangan karakter seseorang dikembangkan melalui nilai luhur. Seringkali dalam kehdupan sehari-hari, ketika seseorang mengalami masalah, pada saat itu jugalah nilai yang ditanamankan pada diri seseorang akan di pengaruhi. Karakter seperti itu atau dinamika karakter di atasi lewat cara mendampingi anak,mensuport atau menguatkan agar lewat cara itu kita bisa memperjelas atau mengetahui karakter anak tersebut. Karakter pada seseorang menjadi ideologi utama dalam pendidikan bukan di nilai dari fisik atau tubuh seseorang.

\footnotetext{
${ }^{4}$ Rannu Sanderan, "Heuristika dalam Pendidikan Karakter Manusia Toraja," BIA' Jurnal Teologi dan Pendidikan Kristen Kontekstual 3, no 2 (December 19, 2020):319, https: //doi.org/10.34307/b.v3i2.213

${ }^{5}$ Rannu Sanderan, "Heuristika dalam Pendidikan Karakter Manusia Toraja," BIA' Jurnal Teologi dan Pendidikan Kristen Kontekstual 3, no 2 (December 19, 2020):318, https: //doi.org/10.34307/b.v3i2.213
} 
ManusiaToraja hidup dalam komunitas yang secara sosial telah terpranatakan dalam kultur khas sebagaimana adanya sebuah entitas suku tradisional. Budayanya yang unik dan bernilai tinggi telah tertata, baik secara artifisial maupun yang intangible ${ }^{6}$. Budaya manusia Toraja dijunjung tinggi sebagai budaya yang unik dan bernilai tertinggi. Komunitas Masyarakat Toraja secara sosial telah dikenal dalam Kultur khususnya dalam entitas suku tradisional. Etika komunal yang ter-didikkan sejak kecil membuat seorang warga Tongkonan tidak bisa menikmati rezeki atau berkatnya bila sendiri saja. Dapat dilihat bahwa dampak pemelajaran nilai etika dalam Tongkonan ternyata lebih berjangka panjang (long term). Pembelajaran Etika tradisional secara eksperimental ini bahkan lebih lanjut akan membentuk seorang anak memiliki integritas diri. Kesetiaan kepada janji dan kejujuran dalam memegang janji adalah suatu kebajikan. Nilai Kesetiaan dan kejujuran memegang janji dapat diedukasikan misalnya melalui narasi tentang Dodeng, mengenai batingna (ratapan) Lebonna dan tindakan Paerengan untuk mewujudkan kesetiaannya ${ }^{7}$. Dalam budaya Toraja, Etika atau karakter seseorang, sudah didik atau mulai di ajarkan kepada anak-anak sejak kecil. Karakter atau etika seseorang sangat diperlukan untuk membetuk kualitas atau integritas pada diri seseorang.

Hubungan Budaya Toraja dengan Karakter Masyarakat Toraja ialah penanaman nilai-nilai keteladanan dalam kehidupan sehari-hari. Karakter Masyarakat Toraja juga bisa dinilai dari cara berbicara, sikap atau perilaku seseorang. Juga adat budaya Toraja mencerminkan ciri Khas Toraja. Budaya Toraja dengan Karakter Masyarakat Toraja sangat berhubungan erat.

Penanaman nilai dan pembentukan karakter tidak memberi tempat pada realita intuisi. Kurikulum yang kaku, seragamisasi, dan kultur"pendidikan model bank"makin mengukuhkan bahwa anak-anak yang berbudaya Asia terkolonialisasi dan tersubordinasi menjadi obyek belaka. Tidak menuntun anak pada kesadaran intuitif dan peniadaan kesadaran afektif; padahal menurut Paulo Freire, otentisitas seorang anak justru dibangun melalui kesadaran kritis (critical consciousness) ${ }^{8}$. Penanaman nilai dan pembentukan karakter tidak memilik ruang atau tempat pada intuisi,sehingga menjadi kaku.

\footnotetext{
${ }^{6}$ Rannu Sanderan, “Stratifikasi Sosial Kepemimpinan Tradisional dalam Dinamika Demokrasi Modern,”Jurnal Lembaga Genap, 2015-2016, no.1 (2015-2016), https://osf.io/63yai/

${ }^{7}$ Rannu Sanderan, "Heuristika dalam Pendidikan Karakter Manusia Toraja," BIA' Jurnal Teologi dan Pendidikan Kristen Kontekstual 3, no 2 (December 19, 2020):319-320, https: //doi.org/10.34307/b.v3i2.213

${ }^{8}$ Rannu Sanderan, "INTUISI: Pendalaman Gagasan Hans-George Gadamer tentang intuisi sebagai Supralogika", Jurnal Ilmiah Religiosity Entity Humanity (JIREH)2, no 2(Desember 2020): 115, https://ojsjireh.org/index.php/jireh/article/view/39
} 
Intuisi seseorang memengaruhinya dalam membentuk orientasi terhadap sesama manusia dan akhirnya juga turut berperan dalam berbagai tindakan religius dan pertimbangan serta pengambilan keputusan etis. Pemahaman seseorang terhadap dirinya dan lingkungannya pun tidak mungkin terbebas dari kondisi kekinian di mana ia hidup dan berinteraksi secara sosial. Untuk keilmuan yang indentik dengan konsep intuisi (misal, teologi, hukum, dan sastera) Gadamer memberi contoh dalam bidang teologi yakni seorang pengkhotbah pertama-tama memahami Alkitab dan menafsirkannya secara teologis kemudian mengaplikasikan interpretasi itu dalam khotbahnya menurut kekiniannya. Di dalam proses itu tampak seolaholah aplikasi terpisah dari pemahaman dan interpretasi. ${ }^{9}$ Sikap atau karakter seseorang akan di pengaruhi dalam pembentukan karakter hidup juga dalam pengambilan keputusan.

Budaya modernisme dan globalisasi membawa berbagai kemudahan bagi umat manusia. Secara perlahan namun pasti manusia diindoktrinasi oleh lingkungannya untuk menjadi makhluk-makhluk pemburu kesenangan yang tidak pernah terpuaskan. Berbagai cara dilakukan oleh manusia untuk mencari kepuasan bagi dirinya, keluarganya atau kelompoknya. Jika disimak dengan baik kriminalitas dan penyakit sosial yang semakin meningkat akhir-akhir ini pada umumnya disebabkan oleh keinginan untuk mencari kenikmatan. Realita ini semakin disuburkan oleh membudayanya selera instan, segalanya harus cepat. Akhirnya manusia menjadi asing dengan penyangkalan diri, menurunnya pengendalian diri, kemampuan untuk menahan penderitaan dan tekanan hidup semakin lemah. Semakin jarang orang yang mampu untuk bekerja di bawah tekanan apalagi bersukacita atau tetap berbahagia di tengah kesulitan ${ }^{10}$. Lingkungan masyarakat yang baik (dalam konteks dominan) memegang teguh nilai-nilai dan norma-norma perilaku yang baik, sejatinya dapat menyokong kehidupan keluarga (Kristen) yang tinggal dalam suatu lingkungan secara baik pula. Tetapi jika yang terjadi adalah sebaliknya, di mana masyarakat tidak lagi memedulikan nilai-nilai atau norma-norma perilaku yang baik karena pengaruh perkembangan zaman atau hal lain, maka diduga kuat bahwa pengaruhnya akan bersifat negatif. ${ }^{11}$ Perilaku atau sikap juga dipengaruhi dari lingkungan sekitar. Akibat adanya pengaruh dari lingkungan, dimana ada masyarakat yang tidak lagi mempedulikan nilai atau

\footnotetext{
${ }^{9}$ Rannu Sanderan, "INTUISI: Pendalaman Gagasan Hans-George Gadamer tentang intuisi sebagai Supralogika", Jurnal Ilmiah Religiosity Entity Humanity (JIREH)2, no 2(Desember 2020): 117, https://ojsjireh.org/index.php/jireh/article/view/39

${ }^{10}$ Rannu Sanderan, "Disiplin Asketidme dan Harmony Kontribusi Disiplin Bagi Pengembangan Pendidikan Kristen, “Jurnal Pasca Sarjana PAK, NO 1(2016), https://osf.io/frsnz

${ }^{11}$ Rannu Sanderan, "Exemplary Menemukenali Kunci Pendidikan Iman Bagi Anak dalam Keluarga dan pembelajaran Agama di Sekolah" (2021), https://osf.io/bmtrk/.
} 
norma yang ada karena pengaruh lingkungan. Karakter seseorang juga bisa berubah dari perkembangan zaman.

\section{KESIMPULAN DAN SARAN}

\section{Kesimpulan}

Dari penjelasan diatas dapat di simpulkan bahwa Budaya Toraja adalah salah satu budaya di Propinsi Sulawesi Selatan yang dikenal masih sangat kental. Budaya Toraja sangat di junjung tinggi karena memiliki tatanan nilai yang baik. Budaya Toraja dengan hubungannya dengan Karakter Masyarakat Toraja adalah sangat berhubungan erat karena Budaya dan Karakter sering kali dijumpai dan dirsakan dalam kehidupan sehari-hari. Masyarakat Toraja tetap memegang teguh nilai-nilai atau norma-norma kebudayaan secara turun temurun bukan berarti mereka tidak mengikuti perkembangan zaman atau teknologi, namun tetap menerapkan dan atau memegang nilai-nilai tersebut. Dengan adanya nilai-nilai kebudayaan diharapkan untuk mengatasi atau menghilangkan karakter yang tidak baik(buruk) yang terjadi masa sekarang ini.

\section{Saran}

Nilai-nilai kebudayaan tetap dipegang teguh dan dilakukan dalam kehidupan sehari-hari. 


\section{DAFTAR PUSTAKA}

1. Sanderan, Rannu, "Heuristika dalam Pendidikan Karakter Manusia Toraja Tradisional,' BIA'. Jurnal Teologi dan Pendidikan Kristen Kontekstual 3, no. 2 (December 19,2020):319,https://doi.org/10.34307/b v3i2.213

2. Sanderan, Rannu, "Stratifikasi Sosial Kepemimpinan Tradisional dalam Dinamika Demokrasi Modern,” Jurnal Lembaga Genap 2015-2010, no.1 (20152016),https//osf.io/63yai/

3. Sanderan, Rannu, "INTUISI:Pendalaman Gagasan Hans-George Gadamer tentang Intuisi sebagai Supralogika”, Jurnal Ilmiah Religiosity Entity Humanity (JIREH) 2, no 2 (Desember 2020):115-117, https://ojs-jireh org/index.php/jireh/article/view/39

4. Sanderan, Rannu, "Disiplin Asketidme dan Harmony Kontribusi Disiplin Diri Bagi Pengembangan Pendidikan Kristen, "Jurnal Pasca Sarjana PAK, no.1 (2016), https://osf.io/frsnz/

5. Sanderan, Rannu, "Menemukali Kunci Pendidikan Bagi Anak dalam Keluarga dan Pembelajaran Agama di Sekolah, "EXEMPLARY, no.1 (20201), https://osf.io/bmtrk/ 